\section{PP-433 進行性胚細胞腫瑒に対する早期超大量化} 学療法についての臨床的検討

\section{昭和大学 藤が丘病院 泌尿器科}

松田 信泰, 佐藤 雅道, 鈴木 司, 北村 朋之, 後藤 隆太 吉川 裕康, 小野寺 恭忠, 池内 隆夫

【目的】進行性肧細胞腫瘍 5 例に末梢血自家幹細胞移植 (PBSCT)を併用した超大量化学療法を早期に施行し，その有用 性,安全性について検討した. [方法】年齢は 28 才から 50 才, 七 ミノーマ 1 例, 非セミノーマ4 例で, Stage 2B 4 例, Stage 3A 1 例, IGCC 分類は, Good pronosis 1 例, Intermediate pronosis 3 例, Poor pronosis 1 例である. 導入化学療法としてネダプラチ ン $20 \mathrm{mg} / \mathrm{m}^{2}$ 、エトポシド $100 \mathrm{mg} / \mathrm{m}^{2}$ を 5 日間連日投与を行い, 2 コース目からカルボプラチン $250 \mathrm{mg} / \mathrm{m}^{2}$, エトポシド $300 \mathrm{mg} / \mathrm{m}^{2}$, 1 フォマ仆 $1500 \mathrm{mg} / \mathrm{m}^{2}$ を 5 日間連日投与による超大量化学療法 を施行した! [成績]超大量化学療法を 2 コース施行したのは 2 例であり, 5 例すべてが腫場マーカー上 CR となった. IGCC 分類 で, Poor pronosisであった 1 例は 4 か月後に AFP の再上昇を 認め, 超大量化学療法を 2 コース追加し, 腫堭マーカー上 CR と なった.CD34 陽性細胞数は PBSCTに必要とされる $2.0 \times 10^{6} / \mathrm{kg}$ 以上が 2 日間で採取可能であった. 重篤な副作用も認めず,無 菌室設備のない当科でも十分に管理が可能であった!結論】治 療効果が高く, 比較的安全性も高いことから, 通常化学療法が 3 コース以上必要な症例には治療期間の短縮, 早期社会復㷌の面 でも早期超大量化学療法は非常に有用であると思われた。

胚細胞腫瘍 超大量化学療法 PBSCT

\section{PP-434 進行性精巣腫場患者に対する末梢血幹細 胞採取における CD34 陽性細胞数の予測 因子の検討}

\section{神戸大学 大学院 器官治療医学講座 腎泌尿器科学分 野}

村葑 基次, 原 勲, 彦坂 玲子, 原 章二,三宅 秀明

荒川 創一, 守殿 貞夫

目的:進行性精巣腫瘍患者に対して、超大量化学療法が施行され る可能性を考慮して行われた末梢血幹細胞採取における CD34 陽性細胞の採取量の予測因子を検討した。方法:対象は 1994 年 3 月から 1999 年 12 月に当科にて末梢血幹細胞採取を受けた 38 人の進行性精巣腫瘍患者。のべ 124 回の末梢血幹細胞採取に求 いて、採取したCD34 陽性細胞数と臨床病理学的因子との関係を 解析することにより，適切な施行時期と採取量の予測因子を検討し た。成績:1 回あたりの CD34 陽性細胞数の中央値は $5.4 \times 10^{6} \%$ $\mathrm{kg}$ 、患者あたりの CD34 陽性細胞数の中央值は $24.1 \times 10^{6} / \mathrm{kg}$ で あった。単変量解析にて、採取時の白血球数および未熟白血球 (骨喵球+後骨㵦球)の比率が有意にCD34 陽性細胞数と相関し たが、化学療法の回数はCD34 陽性細胞数と逆相関した。多变量 解析において、化学療法の回数および未熟白血球の比率が $\mathrm{CD}$ 34 陽性細胞数の独立した予測因子であった。結論:末梢血幹細胞 採取は First-line chemotherapy 施行中に実施すべきであり、末 梢血中の未熟白血球の比率を測定することは適切な施行時期およ び採取量を予測するうえで有用な指標となり得ると考えられた。 進行性辕巣腫瘍 末梢血幹細胞採取 超大量化学療法

\section{PP-435 精巣腫場の遅発性再発例の検討}

\section{東北大学 医学部 泌尿器科}

大和 隆, 星 宣次, 千葉 裕, 大山 力, 恢藤 信 平松 正義, 竹田 篤史, 青木 大志, 折笠 精一

精巣腫瘍の遅発性再発は初発腫瘍の完全治瘜から 2 年以 上経過して再発した場合と定義され、全体の $3 \sim 4 \%$ に起こ ると考えられている。今回、当教室で経験した精巣腫瘍の遅 発性再発例について検討した。対象は平成元年から平成 11 年 6 月までに新たに精巣腫汮と診断された 145 例で、そのう ち 3 例 $(2.1 \%)$ の遅発性再発例が認められた。3 例とも非七ミ ノーマ成分を有する腫瘍 (病理組織診断では胎览性癌 1 例、 七ミノーマ+絨毛癌 2 例)で診断時に後腹膜リンパ節転移、遠 隔転移を認めた。初回治療から再発するまでの期間は 4 年、 5 年、 9 年であったいずれの症例も初発時と比べて化学療 法に抵抗性を示し、転移性腫場を外科的に切除し外来経過 観察中の症例が 1 例、他の 2 例については現在も治療中で ある。これらの精巣腫場の逮発性再発例を文献的考察を加え て報告する。

精巣腫瘍 遅発性再発

\section{PP-436 精巣腫瘍導入化学療法における腫瘍マ一 カー半減期測定の有用性}

\section{筑波大学 泌尿器科}

山本貫大, 河合 弘二, 小羍 学, 宮永 直人, 服部一紀 内田 克紀, 島居 徹, 赤座 英之

【目的】精巣腫場の導入化学療法における腫場マーカー (AFP、 $\beta H C G$ )の生物学的半隇期 (以下 HL と略す) 測定の 有用性について検討する。【法】当院にて1983 年から 1998 年までに導入化学療法を施行後 2 年以上の経過観察 を行った非セミノーマ(stageII 以上) 27 例を対象とした。HL は導入化学療法開始後 7 日目前後のマーカー測定日と测定 值を D1 と M1、3クール目開始前のマーカー最終測定日と測 定值を $\mathrm{D} 2$ と $\mathrm{M} 1$ として、HL=(D2-D1) × $\log 2 / \log M 1-\log M 2$ で算出した。成績】全症例の HL の平均值は AFP で 7.4 (4.5-12.4)、BHCGで5.1 (3.3-10.3)であったIGCC 分類で

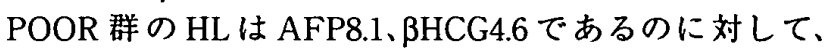
INT/GOOD 群の HLは AFP6.9、BHCG5.9であり、HLと治 療前予後因子の間に明らかな相関は認めなかった。一方、2 年非再発生存率との相関では、AFPの HL が 7.4 末満の症 例で $83 \%$ であるのに対して 7.4 以上の症例では $56 \%$ で あった。同様に $\beta$ HCG の HL が 5.1 未満の症例で $80 \%$ であ るのに対して 5.1 以上の症例では $60 \%$ であった。結論】HL の延長する症例では予後が不良である傾向を認め、導入化 学療法における HL 測定の有用性が示唆された。 精巣腫瘍 腫瘍マーカー 生物学的半減期 